\title{
Financial Resources Management in Commercial Banks: Evidence From
} Latvia

\author{
Natalia Konovalova ${ }^{1} \&$ Aina Caplinska ${ }^{2}$ \\ ${ }^{1}$ RISEBA University of Applied Sciences, Riga, Latvia \\ ${ }^{2}$ Daugavpils University, Daugavpils, Latvia \\ Correspondence: Natalia Konovalova, RISEBA University of Applied Sciences, Meža str.3, Riga, Latvia. Tel: \\ 371-2-921-5208. E-mail: natalija.konovalova@riseba.lv
}

Received: October 31, 2020

Accepted: December 4, 2020

Online Published: February 1, 2021

doi:10.5430/ijfr.v12n1p369

URL: https://doi.org/10.5430/ijfr.v12n1p369

\begin{abstract}
Financial resources management issues are relevant for each commercial bank. Those banks that operate with an excess of free financial resources lose profitability, but the liquidity of such banks is quite high. Other banks that conduct aggressive policy aiming to place all the available resources with maximum efficiency, are forced to seek solutions to the problem of locating additional liquid funds, in order to ensure timely fulfilment of liabilities. In this article, the authors analyze the state of the resource base of Latvian commercial banks, identify reserves for increasing the efficiency of banks and propose a methodology for optimizing the attraction and placement of resources in commercial banks. Since bank resources management involves two interrelated issues - equity capital management and management of liabilities (attracted and borrowed funds), the authors successively consider two sides of this process. Besides, the process of equity capital and liabilities management is inseparably linked with active transactions, i.e. with the use of resources, therefore the research also focuses on the interrelation between passive and active transactions of the bank and on the development of a methodology for optimizing the attraction and allocation of bank resources. The purpose of the research is to analyse passive operations in Latvian banks, to assess the formation of their resource base and its management, as well as to work out some recommendations on how to update the management of the combined (aggregate) resource base in Latvian commercial banks. The authors have put forward a following hypothesis: the decline in financial resources leads to an increase in the bank's efficiency, and vice versa, the increase in financial resources leads to an inefficient redistribution of funds in the banking activity. During the study, this hypothesis was justified. The theoretical and methodological basis for the research includes scientific works by Latvian and foreign authors, special economic literature, Latvian legislation, regulations of the Bank of Latvia and of the Financial and Capital Market Commission, recommendations of the Basel Committee on Banking Supervision, EU Directives. The authors used such research methods as economic analysis, method of comparison, economic grouping, statistical methods, etc. The application of the proposed methodology for optimizing the attraction and placement of resources is considered on the example of Latvian commercial banks.
\end{abstract}

Keywords: bank resource base, bank liabilities, clients' deposits, equity capital, effective resources

\section{Introduction}

The formation (attraction) of resources is the basis and the priority of a commercial bank activity, its vitally important task without which a bank cannot exist. The process of the creation of bank resource base includes the formation of bank stock capital, the attraction of deposits, the emission of loan securities as well as the search of interbank loans (credits) at financial markets. The ability of the bank to attract deposits and interbank (loans) credits is the main criterion of the bank recognition by other market participants. So, the state of the resource base of a commercial bank, firstly, reflects the assessment of the bank stability and reliability (security) by its clients and depositors, and by other banks, secondly, it is the indicator of the quality of the bank clients service (the quantity and the quality of the facilities offered to the clients, the existence of the bank branch offices (network), the provision of electronic bank services, the politeness of the bank personnel etc.); and, thirdly, characterizes the price policy of the bank, in other words, the ability of the bank managers to react adequately to the market changes in the prices of bank services and other bank products. Since the formation of bank resources comes from the realization of passive 
operations, it is exactly passive operations that are bound to provide the optimal (most often maximal - depending on the desired volume of active operations) amount of the attracted resources of every bank with the least expenditure. Moreover, all bank operations are to comply with the demands of legislative and normative acts, as well as with the recommendations of the supervisory bodies (institutions). At the same time the development of the resource provision (base) is to comply with the realization of the bank principles, aims and its activity plans. It should be noted that in present conditions it becomes more and more difficult for Latvian commercial banks to attract resources on a long-term basis. Clients' desire to obtain long-term credits (for terms over 5 years) is still great, however, only a rare clients will express a wish to sign a deposit agreement with a bank placing their money on the bank account for the term of more than 3-5 years. It causes a situation with a discrepancy in the terms of drawing resources and the resources placement terms. As a result, banks are forced to work either in the conditions of increased risk or to refuse their clients' requests for long-term crediting. The task of the search of long-term resources for Latvian commercial banks is an extremely important and urgent one. It can only be solved by a complex approach to the combined (aggregate) resource base management. At the same time bank resource management demands high qualification managers and bank administration personnel to take right managerial decisions aimed at the consolidation and stabilization of the bank resource base. The problems of bank resources management are covered in the works by Joseph F. Sinkey Jr., Peter S. Rose, Diana McNaughton, Lavrushin O.I., Larionova I.V. and others. However, the issues of optimizing the attraction and allocation of bank resources while ensuring the required liquidity level and achieving the maximum possible profitability level do not get enough attention. At the same time, the practice of Latvian commercial banks shows the need for developing and using the appropriate methods for optimizing the attraction and allocation of resources and for improving the approach to bank resources management. The novelty of the study is that the authors developed a methodology for optimizing the attraction and placement of financial resources and applied it in Latvian commercial banks. As a result of the study, it was found that Latvian commercial banks do not effectively use the available resources and accordingly lose profit. Limitation of the research is 6-years analyzed period (2014 - 2019), which started from period when Latvia enter eurozone ( ${ }^{\text {st }}$ of January 2014).

\section{Literature Review}

The scale of the banks' activities, determined by the volume of active transactions, depends on the total volume of resources at their disposal. Because of a special mediatory character of the commercial banks' activities, their resource base is formed mainly by attracted and borrowed funds, i.e. by liabilities that account for more than $90 \%$ of all the bank resources (Finance Latvia Association, 2020). This makes the banks compete more intensively for attracting resources.

The credit resources market is developing simultaneously with the securities market, where banks act as the sellers of their own securities or as the buyers of state and corporate securities. The presence of insurance, finance and other credit institutions increases the competition in the credit resources market and exacerbates the problem of the surplus cash accumulation by the banks (Joseph F. Sinkey, 2013). At the same time, in spite of the insignificant share of equity capital in the banks' funding sources (less than 10\%), the role and importance of this source in the total resource base of commercial banks are very significant. Firstly, equity capital forms the basis of a commercial bank's activity. Secondly, equity capital performs a protective function ensuring the protection of depositors' interests and the absorption of losses not covered by the current bank's income. Thirdly, equity capital is intended to cover banking risks (Lavrushin O.I., 2012). In the widespread the capital is wealth that helps generate further wealth, encompassing everything that gives personal satisfaction, but also helps generate more wealth. Capital is wealth obtained by the results of his own and then used to produce more wealth (Barmuta, K. et al. 2019). Strong corporate governance provides effective financial decisions connecting with the cost of capital (Mokhova, N. et al. 2018). Studies for the bank specific variables such as total assets, capital, asset non-performing loans, income diversification or costs etc. are using for internal bank assessment, while for external determinants GDP is widely using to capture the external factors influence on the performance of banks. Besides, business tendency also influences on banks (Herianingrum, S. et al. 2019). Authors Saksonova S. and Koḷeda O. identified a stable link between bank capital and GDP growth. They proved this fact in the paper "Evaluating the Interrelationship between Actions of Latvian Commercial Banks and Latvian Economic Growth" (Saksonova S. and Koḷeda O., 2017). After the introduction of Basel III requirements, banks began to increase the volume of capital. Analyzing the situation in banks with government support and in banks without government support, the authors Tatibekova, A. and Bubeyev, M. identified that Basel III capital measures to be less constraining for banks with government support, however, they continued to increase capital in post crisis period. In contrast, changes in capital measures affected bond spreads of banks without government support (Tatibekova, A., Bubeyev, M., 2020). The management of resources in banks in modern conditions is innovative. Latvia needs to focus on the integrated development of all the components of the 
innovation system (Anna A. Mikhaylova et al. 2019). This also applies to the management of banking resources due to the introduction of stricter capital and liquidity requirements. All conditions above mentioned confirm that bank capital management and resources management on the whole is important function for successful bank activity. Characterizing the proportion between equity and debt (liabilities) in Latvian commercial banks it is necessary to note that the share of equity capital in the system of Latvian commercial banks by the end of 2019 was only $9.7 \%$ (FCMC, 2020). Accordingly, the total liabilities in Latvian commercial banks accounted for 90.3\% (FCMC, 2020). The presence of subordinated liabilities (subordinated capital) in the sources of formation of equity capital in many commercial banks of Latvia changes the proportion by $1 \%$ in favour of equity (Finance Latvia Association, 2020). The process of managing the resources of a commercial bank presupposes the efficient use of these resources in accordance with the possibilities of the resource base formation and, vice versa, the formation of the resource base in accordance with the possibilities of its use. The dialectic of these processes is solved by determining the "golden mean" between raising and using bank resources. In this connection, bank resource management is aimed at ensuring the stability and reliability of the bank as well as at optimization of the process of attracting and allocating cash resources (Larionova I.V, 2015). The resource management tasks of the banks are as follows:

- To maintain the equity capital value at the level that is necessary and sufficient for ensuring the bank's reliability as well as for the expansion of profitable active transactions.

- Not to allow the attraction of non-earning resources. This means that the bank should not attract excess deposits and debt securities resources that cannot be deployed in the nearest future.

- To identify and preferentially attract credit resources the quantity and quality of which are necessary and sufficient for carrying out and developing active transactions as well as for the formation of alternative sources for the repayment of the bank's liabilities.

- To raise "cheap" resources mainly in the form of demand deposits for the bank to get profit due to a higher margin between active and passive transactions.

- To ensure the attraction of term deposits and other resources for a certain fixed period of time for enhancing the bank's stability and improving its balance sheet liquidity.

- Not to attract resources of doubtful origin in order to preserve the bank's image and reputation (Lavrushin O.I., 2012).

Evans Tee in the paper "Asset Liability Management and the Profitability of Listed Banks in Ghana" (Evans Tee, 2017) claims that liability management only not enough for financial resources management. He also provides evidences that liability management in some countries has negative effect on bank activity and profitability. The authors of this article believe that the financial resource management process should be considered in connection with operations in bank assets, using Asset Liability Management (ALM). Asset and liability management (ALM) can be defined as the practice of matching the term structure and cash flows of an organization's assets and liability portfolios to maximize returns and minimize risk (Choudhry M., 2007). The general term asset and liability management started to be commonly used from the mid-1970-s. In the past, ALM was a more simplistic process with less regulations and limitations (Choudhry M., 2007). ALM has changed significantly in the past two decades with the growth and integration of financial institutions and the emergence of new financial products and services (Gunay G. et al. 2005). Banks, hedge funds and more generally financial regulated companies engage in complex capital markets activities that involve trading of instruments in derivative or cash form. All these activities contribute to define the company's asset and liability profile and the ability to manage well such a profile is crucial to the success of a business. The financial crisis changed conditions for lending and borrowing and created uncertainty in funding and capital requirements for most financial institutions. Regulations and competitive forces drive the need for an optimization of the liquidity, term gaps and costs of funds within the organizations, which will help them to face new challenges driven by market conditions and to continue to maintain profits for their shareholders (Dalessandro, Antonio, 2013). It should be noted that after the crisis of 2008, the countries of Eastern Europe, including Latvia, showed a trend of mergers and acquisitions of banks and firms. These issues have been investigated by the authors Saksonova S. and Kantāne I. In the paper "Mergers and Acquisitions: Examples of Best Practice in Europe and Latvia" they concluded that in evaluating decisions on the possibilities for mergers and acquisitions Latvian firms and banks have to be guided by the most important results of this process: possible increases in foreign direct investment and the growth in market share (Saksonova S. and Kantāne I., 2016). Asset-liability management basically refers to the process by which an institution manages its balance sheet in order to allow for alternative interest rate and liquidity scenarios (Francis M. E., 2007). Banks and other financial institutions provide services which expose them to various kinds of risks like credit risk, interest risk and liquidity risk. Proper Asset-Liability 
management controls the risks inherent in the business due to mismatches between assets and liabilities (Rosen, D. and Zenios, S. A. 2006). Asset-liability management is an approach that provides institutions with protection that makes such risk acceptable. It is therefore appropriate for institutions banks, finance companies, leasing companies, insurance companies, and others to focus on asset-liability management when they face financial risks of different types. Asset-liability management includes not only a formalization of this understanding but also a way to quantify and manage these risks leading to higher returns and profitability. Further, even in the absence of a formal asset-liability management program, the understanding of these concepts is of value to an institution as it provides a true picture of the risk/reward trade-off in which the institution is engaged (Fabozzi F. J. and Konishi A., 1995).The profitability of banks is vital for the smooth operation of the financial system of a country. Therefore, the sector's profitability is of the major concern for those who are responsible for policy making and operating day to day with it (Kosmidou K. et al. 2004) and (Shubiri A., 2010) identified that among the possible factors that have effect on banks' profitability is the asset-liability management. This therefore implies that if banks are able to properly match their liabilities to assets, then there is the possibility of improving profitability. Although the effect of the management of banks' asset and liability on their profitability has been studied by a number of Latvian researchers as Dalecka S. (2016), Zarembo J (2015)., Kudinska M. (2016), Saksonova S (2006). etc., the issue of banks' profitability and asset-liability management in Latvia has received limited attention from the researchers. The determinants of commercial banks profitability have also been studied by a lot of foreign researchers (Ramlall, I. 2009), (Alper D. and Anbar A., 2011), (Asiri, B. K., 2007), (Kwast M. L. 1982), Peter S. Rose (2012) Joseph F. Sinkey, Jr (2002) found that bank profitability is affected by both internal and external factors. Internal factors are related to bank management considering the asset-liability management practices and external determinants are factors which reflect the economic and legal environment that affect the operation and performance of commercial banks. The efficient composition of assets and liabilities of commercial banks is crucial for their sound financial performance (Golbert, L. and Rai, A. 1996). All above mentioned allow doing conclusion that financial resources management in commercial banks is bilateral process, which based on asset-liability management or based on optimization of attraction and allocation of funds.

\section{Formation of the Resource Base in Latvian Commercial Banks: Overall Trends}

As is known, the resource base of commercial banks is formed by carrying out passive transactions. However, not all the liability items of the bank can be regarded as resources. Resources are understood to mean a certain part of the bank's liabilities (the total of equity and liabilities) which is the source of funding active transactions. So, resources, in the authors' opinion, must be formed (raised, borrowed, capitalized, etc.) and intended for efficient deployment in active transactions. Thus, resources will include the following liability items: clients' deposits, amounts owed to credit institutions, debt securities issued by the bank, subordinated capital (subordinated liabilities), capital and reserves. Other liability items, such as deferred income and accrued expenses, provisions for liabilities and charges, other liabilities, including accounts payable related to the bank's internal business transactions, are non-resource liabilities. As can be seen in Figure 1, clients' deposits have the biggest share in the funding sources. For the analyzed period $(2014-2019)$ the share of clients' deposits in the sources of formation of the banks' resource base increased from $72 \%$ to $77.6 \%$, but their growth rates are declining. Share of liabilities to credit institutions is quite small (not more than $12 \%$ for the analyzed period) and also has declining trend. Capital and reserves are an important funding source. They enable commercial banks to determine their starting position at the initial stage of operation, and later, to implement their development strategy. In recent years (2014-2019), commercial banks in Latvia have been operating with the share of capital and reserves not exceeding 12.7\%. Debt securities (bank bonds and mortgage bonds) issued by Latvian commercial banks account for a very small share of the funding sources (only 1-2\%), and their share is declining for the analysed period. This is due to a decrease in the number of banks issuing debt securities. However, authors consider that this source of banks' financial resources has good prospects for the development and can increase together with securities market development, will provide alternative sources of banks' funds and to strengthen the resources base of commercial banks in future. The composition and structure of Latvian commercial banks' liabilities (shareholders' equity and liabilities) in $2014-2019$ are shown in Figure 1. 


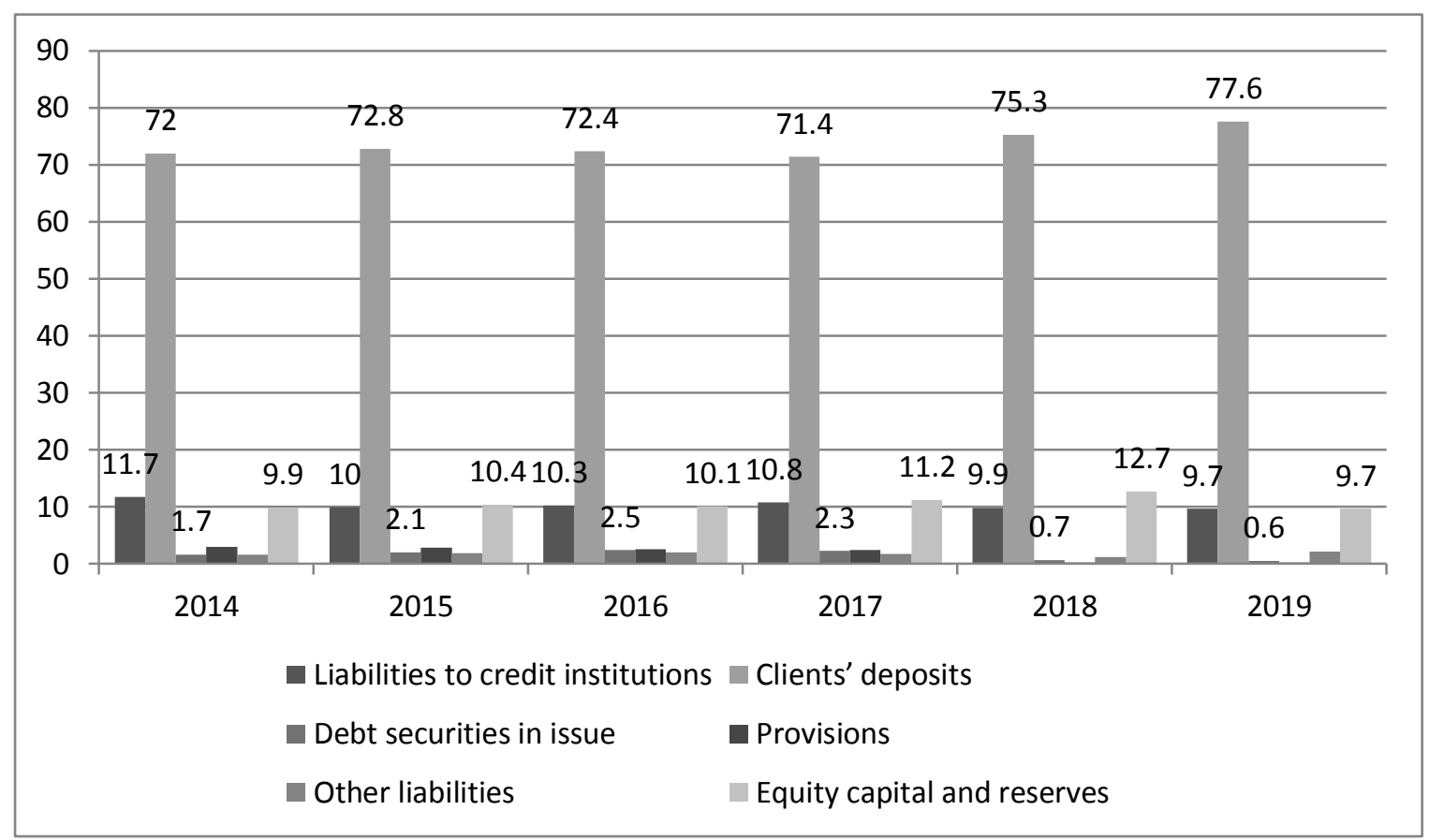

Figure 1. Structure of liabilities in Latvian commercial banks for the period $2014-2019$ (prepared by the authors basing on Latvian Financial and Capital Market Commission data, Finance Latvia Association data)

In general analyzing the dynamics of changes in the main types of banking resources in the commercial banks of Latvia for the period from 2014 to 2019 (Figure 2), can conclude about the critical state of the banking system of Latvia.

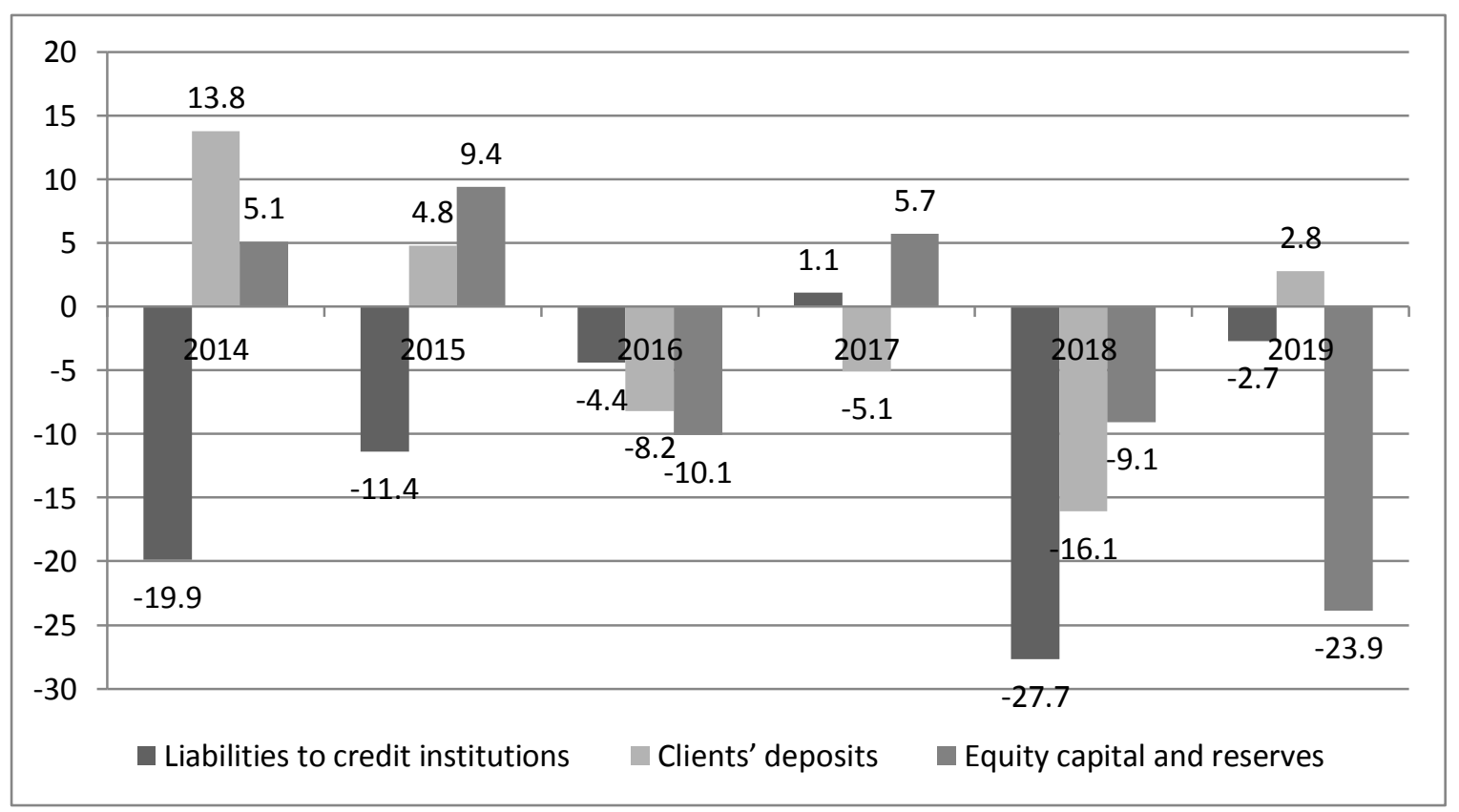

Figure 2. Growth/decline rate of the main types of resources in Latvian commercial banks for the period 2014-2019 (developed by the authors basing on Latvian Financial and Capital Market Commission data, Finance Latvia Association data, and Latvian commercial banks data) 
There is a downward trend in all types of resources. The sharp decrease in client deposits is associated with state policy aimed at preventing money laundering and closing accounts of non-resident customers. In 2018, one of the largest commercial banks, which serviced non-resident customers, was closed in Latvia that led to a significant reduction in the total volume of deposits. The decrease in liabilities to credit institutions is due to the excess of resources compared to their placement in income assets. Banks currently do not need additional resources as interbank loans. Despite the general decrease in resources, the Latvian banking system has an excess of efficient resources, the market for placing resources is reduced, and as a result, the demand for resources is reduced. The decrease in equity in 2018-2019 is associated with the liquidation of two large banks during this period (ABLV Bank and PNB Bank).

\section{Equity Capital of a Commercial Bank: Analysis and Management}

Equity capital of a commercial bank constitutes the basis of its activity and is an important source of financial resources. Capital is meant to support customer trust in the bank and to prove its financial stability to creditors (Larionova I.V, 2013). The size of the equity capital of a commercial bank should be adequate for ensuring the borrowers' confidence in the bank's ability to meet their borrowing needs. In its turn, the depositors and creditors' trust in the banks strengthens the stability and credibility of the country's banking system in general. For these reasons, banking supervisory bodies pay special attention to the size and structure of equity capital, and the capital adequacy ratio is considered to be one of the most important indicators for assessing the credibility of a bank. Capital management means forecasting the size of the capital taking into account the growth of the volume of its balance sheet and off-balance-sheet transactions, the size of risks taken by the bank and the compliance with the proportion between different elements of the capital, established by relevant regulations. Thus, in the authors' opinion, the objects of capital management are the absolute value of equity capital, equity capital adequacy, the relationship between Tier 1 and Tier 2 capital, the structure of elements within each tier, capital formation costs and return on equity. We will now analyze the state of the capital management objects in the system of Latvian commercial banks. As shown in Figure 3 the amount of equity capital in Latvian commercial banks is decreased from 3038873 thousand euros in 2014 to 2187882 thousand euros in 2019.

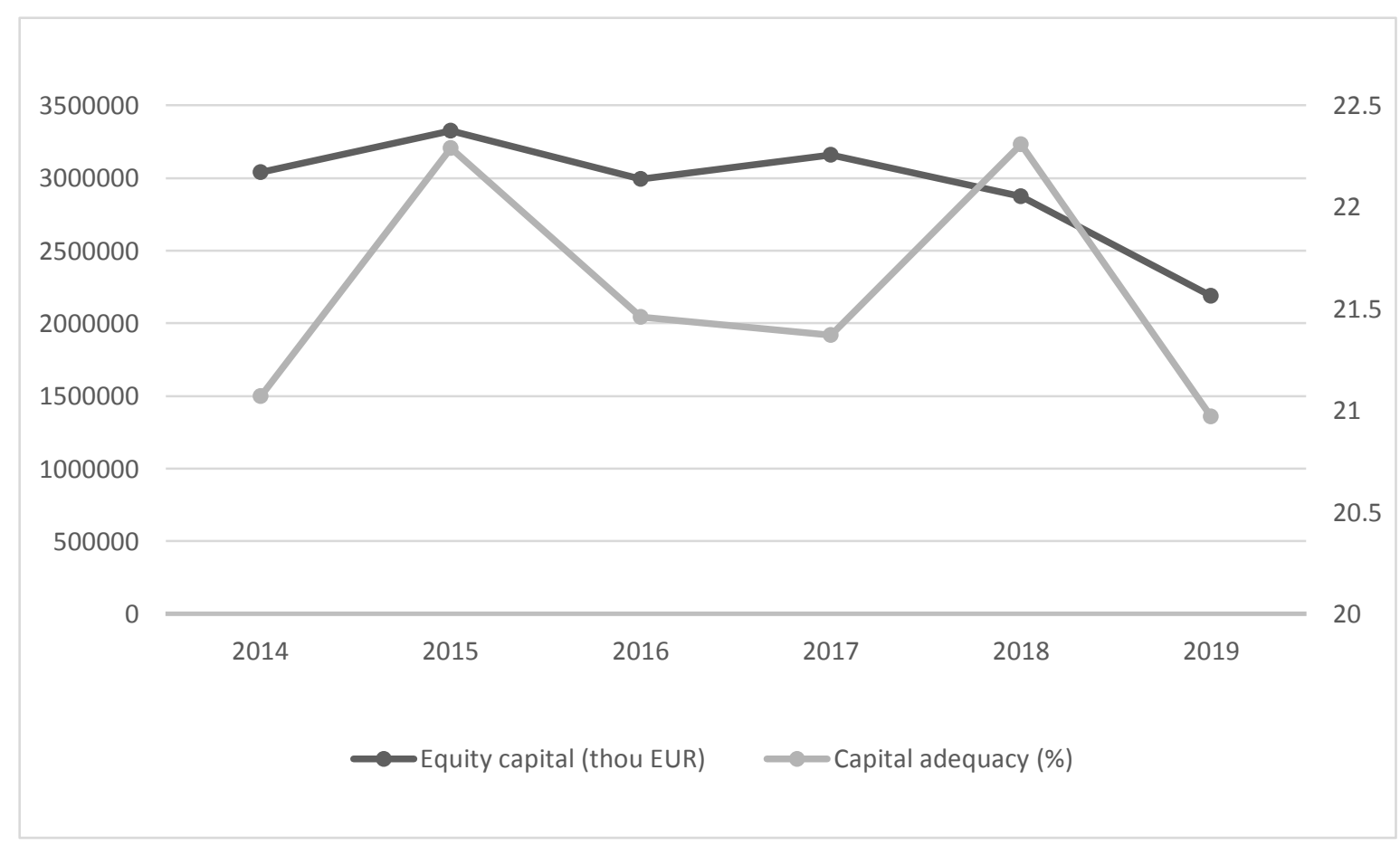

Figure 3. Change in the capital adequacy ratio and in the amount of equity capital in Latvian commercial banks in 2014-2019 (prepared by the authors basing on Latvian Financial and Capital Market Commission data, Finance Latvia Association data)

Capital adequacy ratio is on the level more than $20 \%$ for the analyzed period and fluctuations in capital adequacy 
ratio are insignificant, they are from $20.97 \%$ to $22.31 \%$. As mentioned above the substantial decrease in equity capital in Latvian banking system in 2019 is associated with the liquidation of two large banks (ABLV Bank and PNB Bank). But if we look at the each individual bank we can observe situation that the equity capital sum and capital adequacy ratio in each individual bank are increased. There are 13 commercial banks in Latvia now, and annual reports of each commercial bank show an increasing trend in equity capital sum and in capital adequacy ratio. This opposition between trend of Latvian banking system in whole and individual banks can be explained by reduction in the number of banks in Latvia, but not by internal bank management. The internal policy of each individual bank, that operates in Latvian financial market aimed to strengthening of equity capital and its adequacy. It should be noted the economic instability and crisis phenomena of the recent years have led to higher banking risks and lower income, which, in its turn, requires bigger equity capital in each individual bank. When analyzing the capital adequacy dynamics, it is possible to make a conclusion that this indicator, in the system of Latvian commercial banks, is stable and varies between $20 \%$ and $22 \%$, which fully corresponds to the regulatory requirements. In accordance with the requirements of the Basel Committee and of the Financial and Capital Market Commission (FCMC), the capital adequacy ratio must not be lower than $8 \%$, and not be lower than $10,5 \%$ including capital buffer. It is also necessary to note that the capital adequacy ratio, in the system of Latvian commercial banks, was maintained at a constant level due to the adequate growth of capital in accordance with the growth of the risky assets volume. An important role in the bank's capital management is played by the analysis of the capital elements and the analysis of the relationship between Tier 1 and Tier 2 capital.

The analysis of the elements of commercial banks' capital shows that Tier 1 capital consists of more stable elements. In their turn, the elements of Tier 2 capital ensure the total capital increase from internal and external sources and optimize the volume of the bank's total capital. When analyzing the relationship between Tier 1 and Tier 2 capital in the system of Latvian commercial banks, it is necessary to note that Latvian commercial banks observe the set limits regarding the relationship between the two tiers of capital, but are not active enough in using the opportunities for increasing Tier 2 capital. Thus, during the analyzed period, from 2014 to 2019, the share of Tier 1 capital varied between $87 \%$ and 93\%, while the share of Tier 2 capital elements was only $6.9 \%-13.0 \%$ (see Figure 4). The analysis of the capital elements shows that the bank has the opportunity to increase Tier 1 and Tier 2 capital using both internal and external sources. The main external sources for the increase of Latvian commercial banks' capital are the issue and allotment of shares (increase of Tier 1 capital) and attraction of subordinated capital (increase of Tier 2 capital). Issue and allotment of shares is an expensive way of capital increase due to high preparation costs for the new issue. In addition, there appears a risk related to the shareholder income as compared with that of debt instrument holders. At the same time, the additional issue of shares leads to the growth, as a rule, of three elements of the bank's capital: share capital, share premium and reserves tied to the value of share capital. The increase of capital using subordinated sources (subordinated liabilities) means obtaining long-term loans with at least 5-year maturity for the replenishment of capital, with the agreed procedure of repayment in case of the bank's bankruptcy. These subordinated liabilities are repaid, in case of the bank's bankruptcy, after satisfying the claims of all creditors, but in priority to shareholders. The share of subordinated capital in the funding sources of Latvian commercial banks is not big - not exceeding 1\%, but it tends to grow. The main source for the internal growth of capital is profit accumulation. It is often the easiest and the cheapest way of capital replenishment, especially for banks having a high rate of return. Besides, when capital is raised using internal sources, there is no threat that the existing shareholders will lose control of the bank and that the dividend yield will go down. However, it is necessary to take into account that the bank's profit is determined by its credit, investment, financial and dividend policy, which means that the bank's transactions may result both in the increase of capital and in the decrease of capital due to loss. 


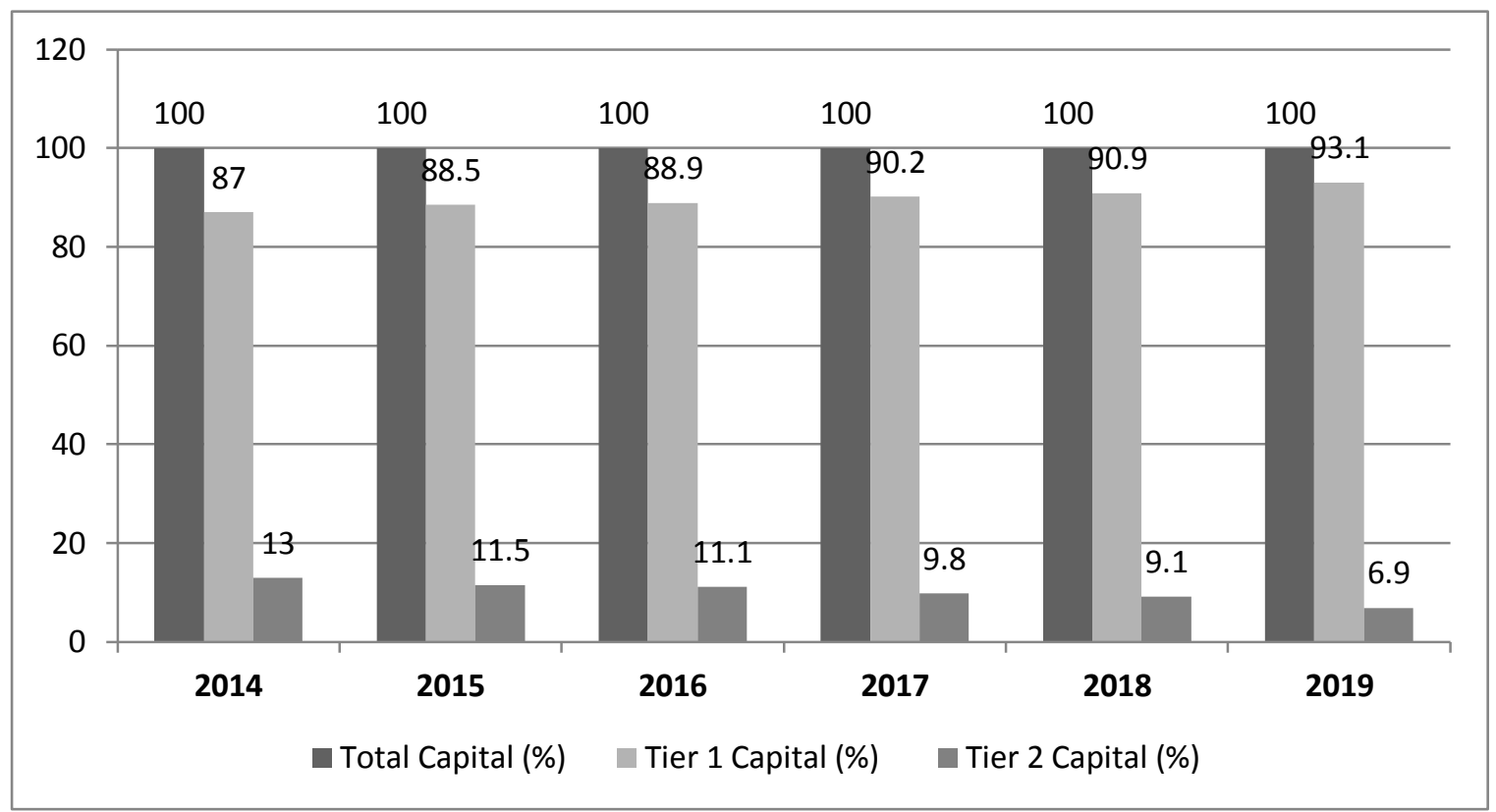

Figure 4. Change in the relationship between Tier 1 and Tier 2 Capital in the system of Latvian commercial banks in 2014 - 2019 (calculated by the authors basing on Latvian Financial and Capital Market Commission data, Finance Latvia Association data)

The amount of profit remaining at the bank's disposal is of primary importance for the bank's capital management. A low level of profit leads to a slow growth of internal sources of capital. A high share of profit used for increasing the bank's capital leads to smaller dividends (Lavrushin O.I., 2012). At the same time, high dividends contribute to the growing market value of the bank's stock which makes it easier to raise capital from external sources. In this connection, when managing the capital for ensuring its acceptable growth based on the use of internal and external sources, it is necessary to ensure the implementation of an optimal dividend policy. In the author's opinion, the optimal dividend policy is the one that maximizes the market value of the shareholders' investment. The bank will be able to attract new shareholders and to retain the existing ones, if return on invested capital is, at least, equal to the return on investment in other spheres of business with the same level of risk. In managing their capital, the banks face an important task of developing a stable dividend policy. When the share of dividends is maintained at a relatively constant level, investors regard them as sufficiently stable income, and the bank looks more attractive to them.

Latvian commercial banks are rather active in using the source of internal capital growth by increasing the share of retained earnings in it. Thus, during the period from 2014 to 2018, the share of retained earnings was more than 20\% of the funding sources. However, in 2019 share of retained earnings is decreased and accounted $11.5 \%$ only (Figure $5)$. 


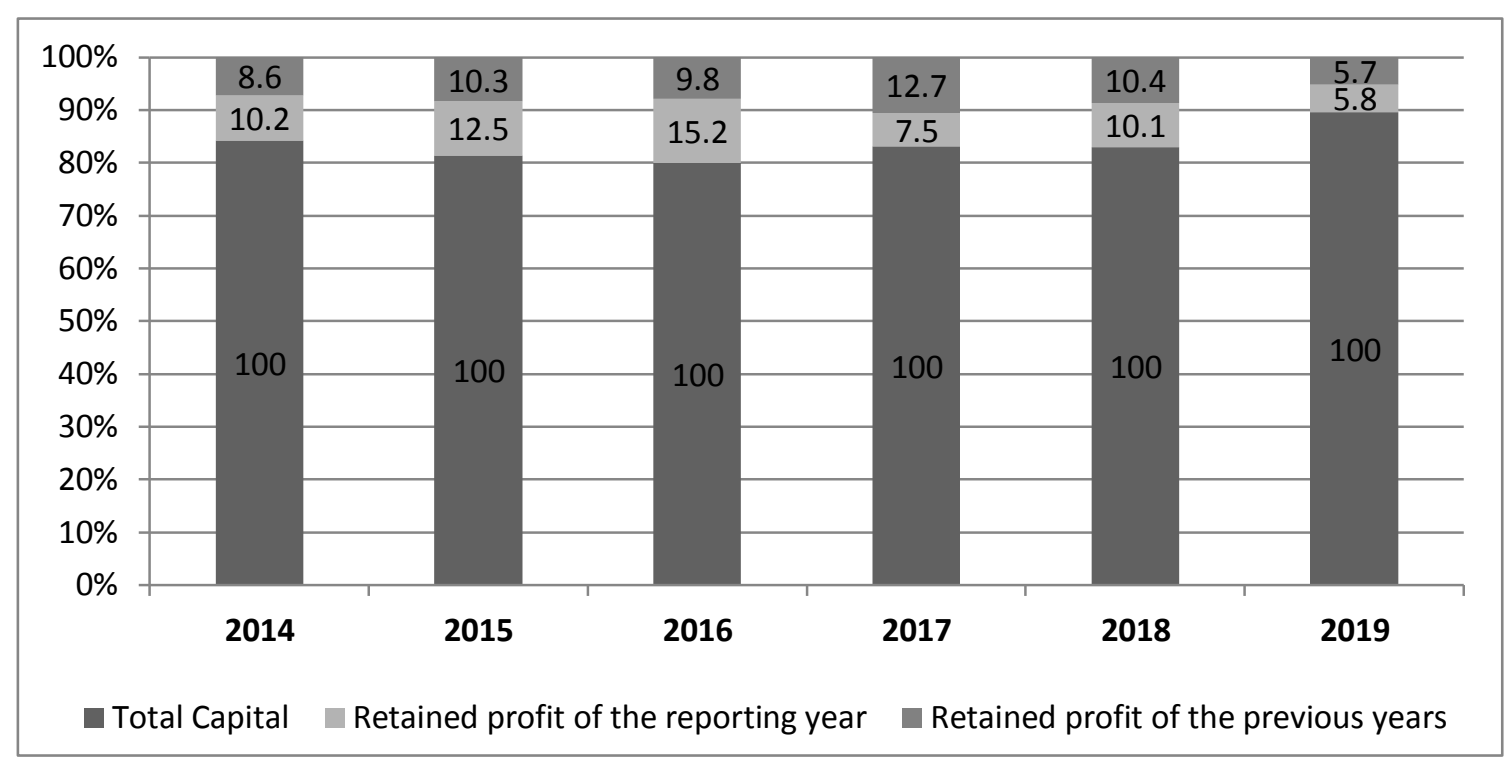

Figure 5. Change in the share of retained earnings from the accounting year in the sources of formation of equity capital in Latvian commercial banks in 2014 - 2019 (calculated by the authors basing on Latvian Financial and Capital Market Commission data, Finance Latvia Association data)

It is explained by reduction of incomes in commercial banks and as consequence a decreasing of retained earnings. The correlation between the internal and external sources of capital increase is often determined by the size and the strategy of the bank. Large banks having access to national and international financial markets have an opportunity to issue shares for continuous growth of their operations. The opportunities of smaller banks are limited. As a rule, they cannot attract investors, since they do not have the adequate reputation for that. Besides, the small-size issues of shares are difficult to sell in the market and their allotment is associated with high costs and risks. For this reason, smaller banks should mostly rely on internal sources of capital increase (Lavrushin O.I., 2012). Capital management must ensure its efficient use by the bank, so it is necessary to analyze the change in return on equity (ROE). Evaluation of return on equity ratio showed that during last 3 years $(2017$ - 2019) the efficiency of equity capital is decreased. As evident from Figure 6 the return on equity ratio is decreasing even if share of capital is increased (especially it is observed in 2017).

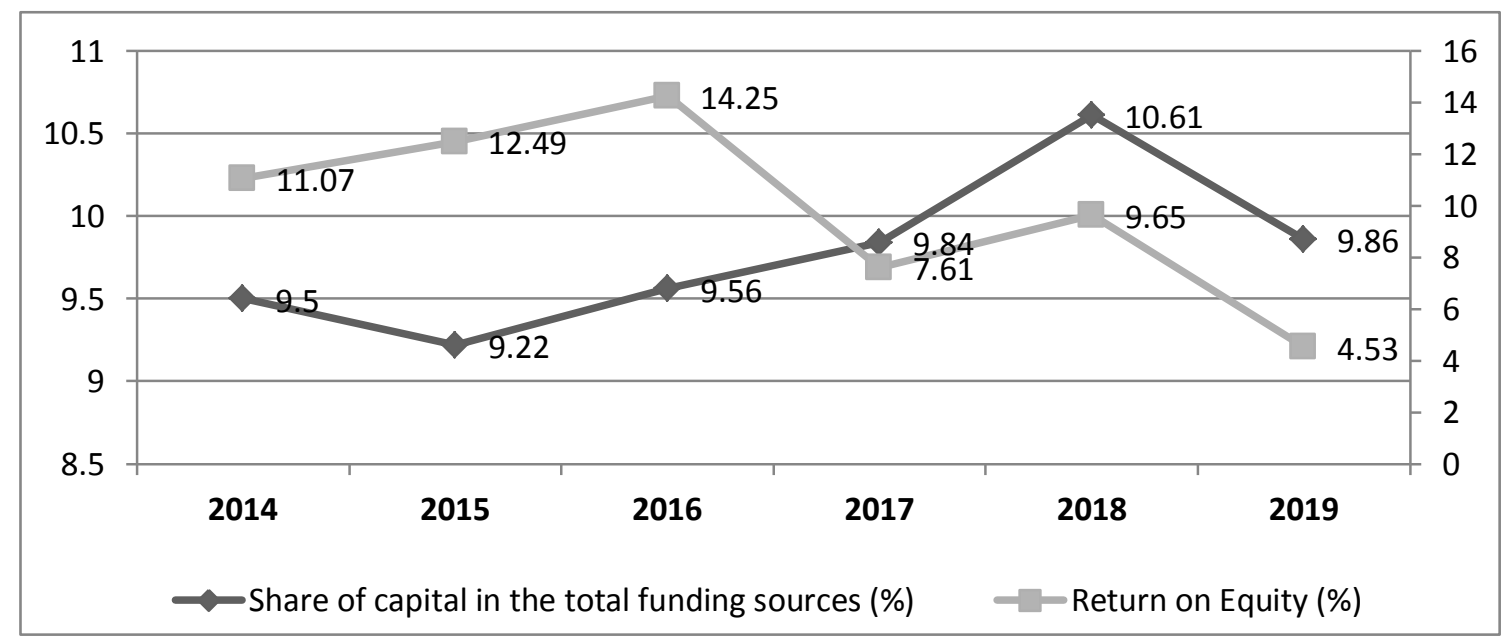

Figure 6. Share of capital in the total funding sources and return on equity ratio in the system of Latvian commercial banks in 2014-2019 (prepared by the authors basing on Latvian Financial and Capital Market Commission data,

Finance Latvia Association data) 
Moreover, return on equity ratio has a large fluctuation $(4.53 \%-14.25 \%)$ during the analyzed period. Thus, the biggest ROE ratio $14.25 \%$ was in 2016 , while share of equity capital amounted $9.56 \%$ only. This meant a high efficiency of share capital using in 2016 due to the rise of earning operations. Further tendency was connected with more quickly rising of equity capital share and less quickly rising of return on equity ratio (2018). In 2019 the both indicators (share of equity capital and ROE ratio) were reduced and reached minimum mark for the analyzed period (2014-2019) and amounted 9.86\% and 4.53\% accordingly. It is a reflection of earning operations decrease in Latvian banking sector. In view of the fact that many Latvian commercial banks lack long-term debt resources for covering long-term active transactions, capital management should focus on its long-term planning. Equity capital should be planned on the basis of the general financial plan of the bank. Capital planning is preceded by the work on determining the growth rate and the structure of the bank's active transactions, i.e. by a pro forma balance sheet of the active transactions. At the next stage it is necessary to determine the required sources of financing of active transactions, to forecast the amount and sources of funds (deposit and non-deposit), to assess the composition of assets by the degree of risk based on the bank's strategy. These data form the starting basis for developing the bank's income plan taking into account different scenarios of interest rate movements and the expected level of non-interest income and expenses. The forecast of dividend payments is used as a basis for determining the possible amount of internally generated capital, i.e. the amount of profit that can be used for capital increase. Based on the planned asset growth, the required amount of capital raised from external sources is calculated. Thus, the long-term capital planning can ensure the optimization of Tier 1 and Tier 2 capital and help achieve a balance between the maturity and amounts of the bank's resources and their allocation.

\section{Commercial Bank's Liabilities: Analysis and Management}

Total liabilities of the bank consist mainly of attracted resources which, in their turn, are subdivided into two large groups: deposit resources and non-deposit resources. Deposit resources acquired from corporate and retail clients are represented by core deposits and volatile deposits (Choudhy, M. 2007). Core deposits constitute a permanent deposit base of the bank. They are usually based not on separate transactions, but on long-term relations of the bank with the client, their fluctuation as to timing and amounts is not substantially affected by the change in the interest rates (i.e., they are not rate-sensitive). However, core deposits are potentially subject to significant fluctuations depending on the client's activity, cash flow and other factors. Core deposits, as a rule, are represented by demand deposits which are the lowest-cost part of the bank's deposit base. Volatile deposits are term deposits that are attracted to the bank by the interest rate; therefore, they tend to migrate if the rate on deposits changes unfavourably. A high share of volatile deposits in the attracted resources makes the bank dependent on the financial market trends, including the change in the interest rates. At the same time, term deposits being volatile deposits are the highest-cost part of bank resources. They are rate-sensitive, but more stable resources as compared to demand deposits (Adam, A. 2008). Non-deposit resources are acquired by the banks mainly by borrowing money from other credit institutions, including the central bank, as well as by issuing debt instruments (bonds, mortgage bonds, etc.).

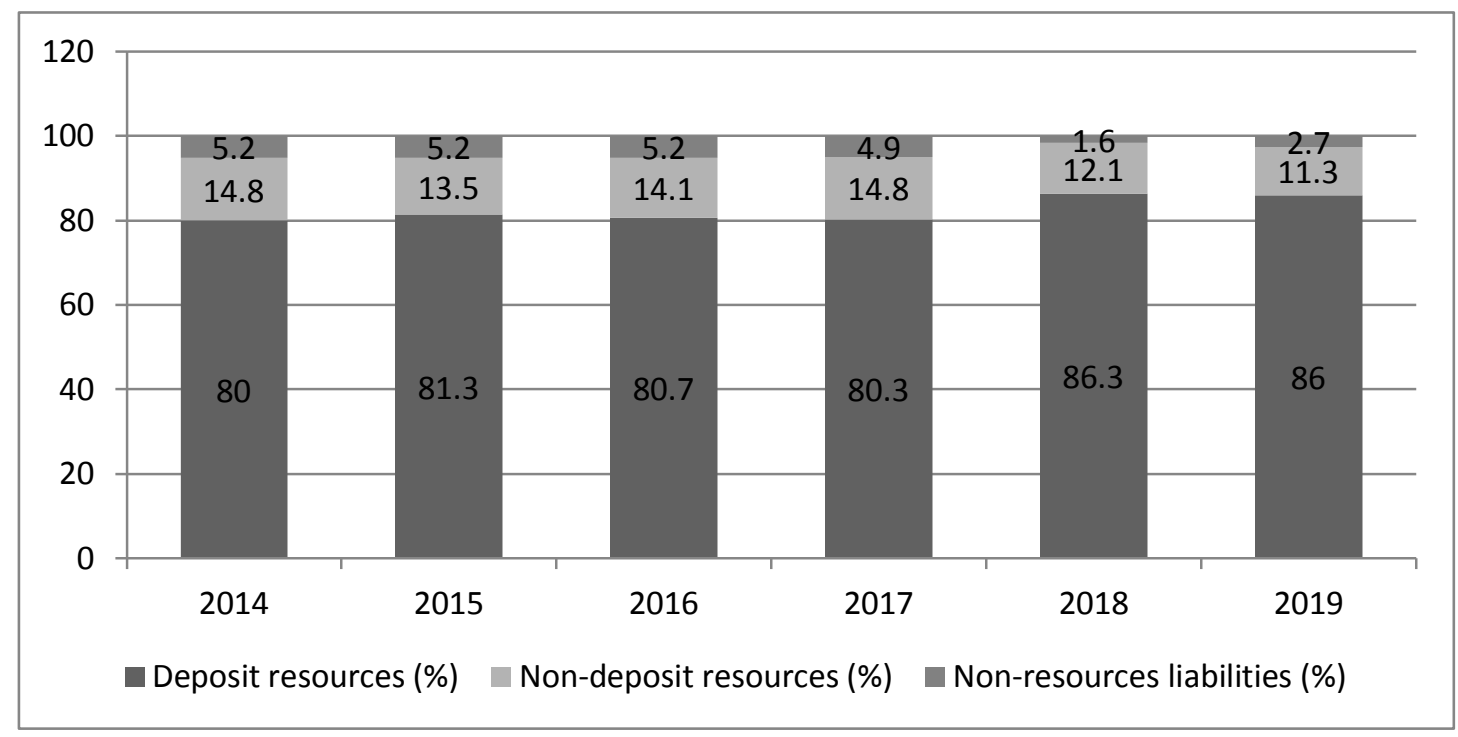

Figure 7. Change in the share of deposit, non-deposit and non-resource liabilities in total liabilities of Latvian commercial banks in 2014 - 2019 (prepared by the authors basing on Latvian Financial and Capital Market Commission data, Finance Latvia Association data) 
Analyzing the structure of liabilities of Latvian commercial banks for 2014 - 2019 years (Figure 7), it can be concluded that deposit resources make up the highest share $(80-86 \%)$. In turn, in the composition of deposit resources, the largest share is occupied by demand deposits, which are the main source of placement of funds in active short-term operations. However, in the Latvian banking system there has been a rate of decline in demand deposits due to the fact that many banks have reduced the service of non-resident customers' accounts. It should be noted that Latvian commercial banks also use interbank loans as part of their resources, but their share in the sources of banking resources formation is insignificant - only $11-14 \%$.

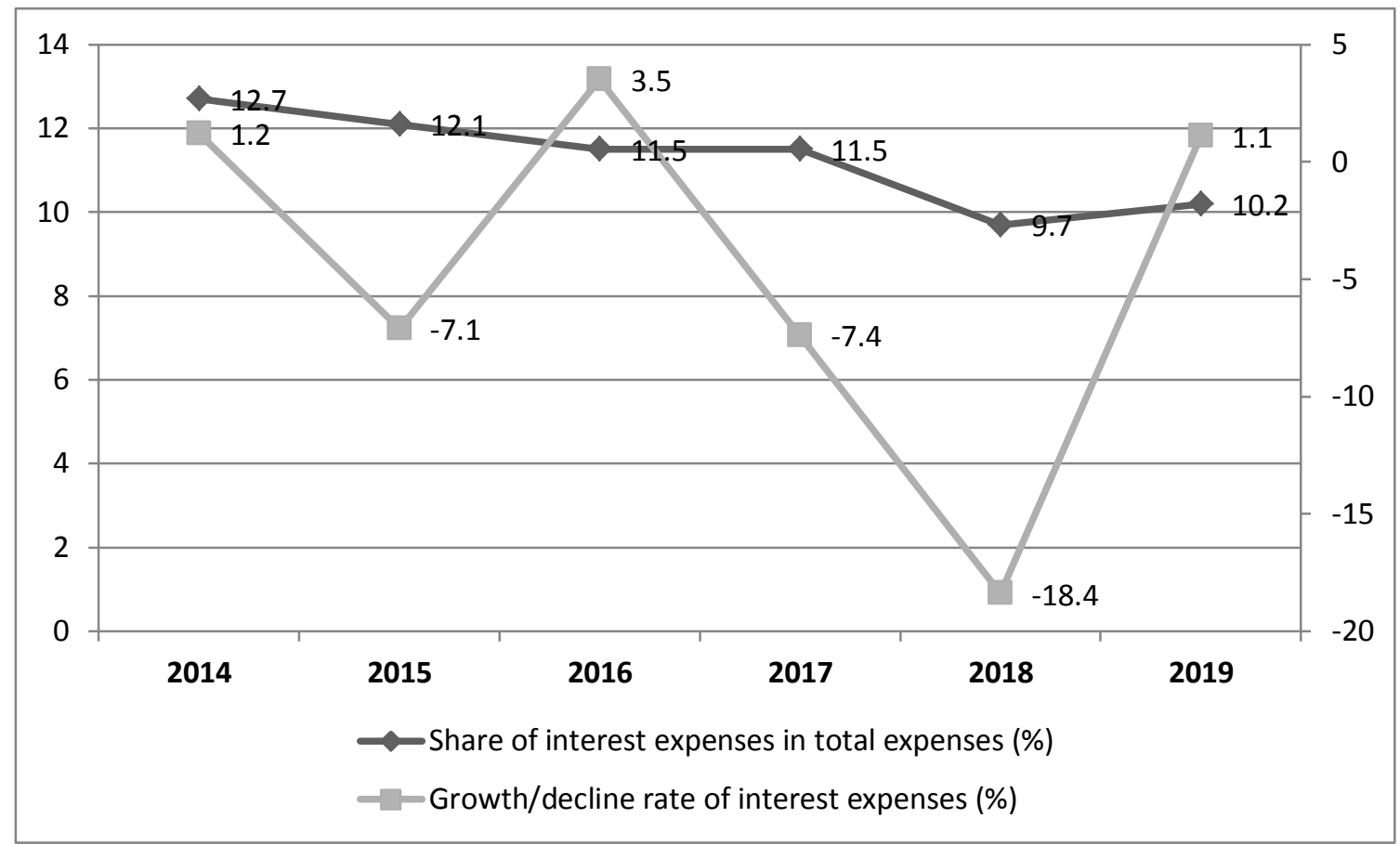

Figure 8. Share of interest expenses in total expenses in Latvian commercial banks and growth/decline rate of interest expenses (calculated by the authors basing on Latvian Financial and Capital Market Commission data, Finance Latvia Association data)

In liability management, the banks need to control the level of interbank loans and to make sure that they do not turn into a permanent funding source. If interbank loans occupy the main place in the attracted resources, the unfavourable state of the interbank market can lead to liquidity problems and to the outflow of a substantial part of resources from the bank. Resources attracting is associated with costs, namely, interest expenses of the bank. The authors revealed that interest expenses amount a small share of the total expenses of Latvian commercial banks. Thus, it was found that for the analyzed period from 2014 to 2019, the share of interest expenses in total expenses fluctuated from $9.7 \%$ to $12.7 \%$ (Figure 8). However, during the analyzed period there was a rate of decline in interest costs in Latvian commercial banks. The authors revealed that the most significant leap in the rate of decrease in interest expenses (-18.4\%) was recorded in 2018 (Figure 8), precisely at the time when one of the largest Latvian banks was liquidated. This means that the withdrawal from the market of a large bank significantly affected the entire banking system. Analyzing the composition and structure of interest expenses of commercial banks, we can conclude that the largest share $(36.4 \%-43.3 \%)$ is client deposit expenses (Figure 9), despite the fact that interest rates on deposits are currently very low in Latvian commercial banks (Figure 10). Figure 10 shows the dynamics of average deposit rates in Latvian commercial banks, as well as the dynamics of deposit rates of the European Central Bank, which are negative. The factor of negative interest rate of the European Central Bank also significantly affected the decrease in total interest costs of banks. 


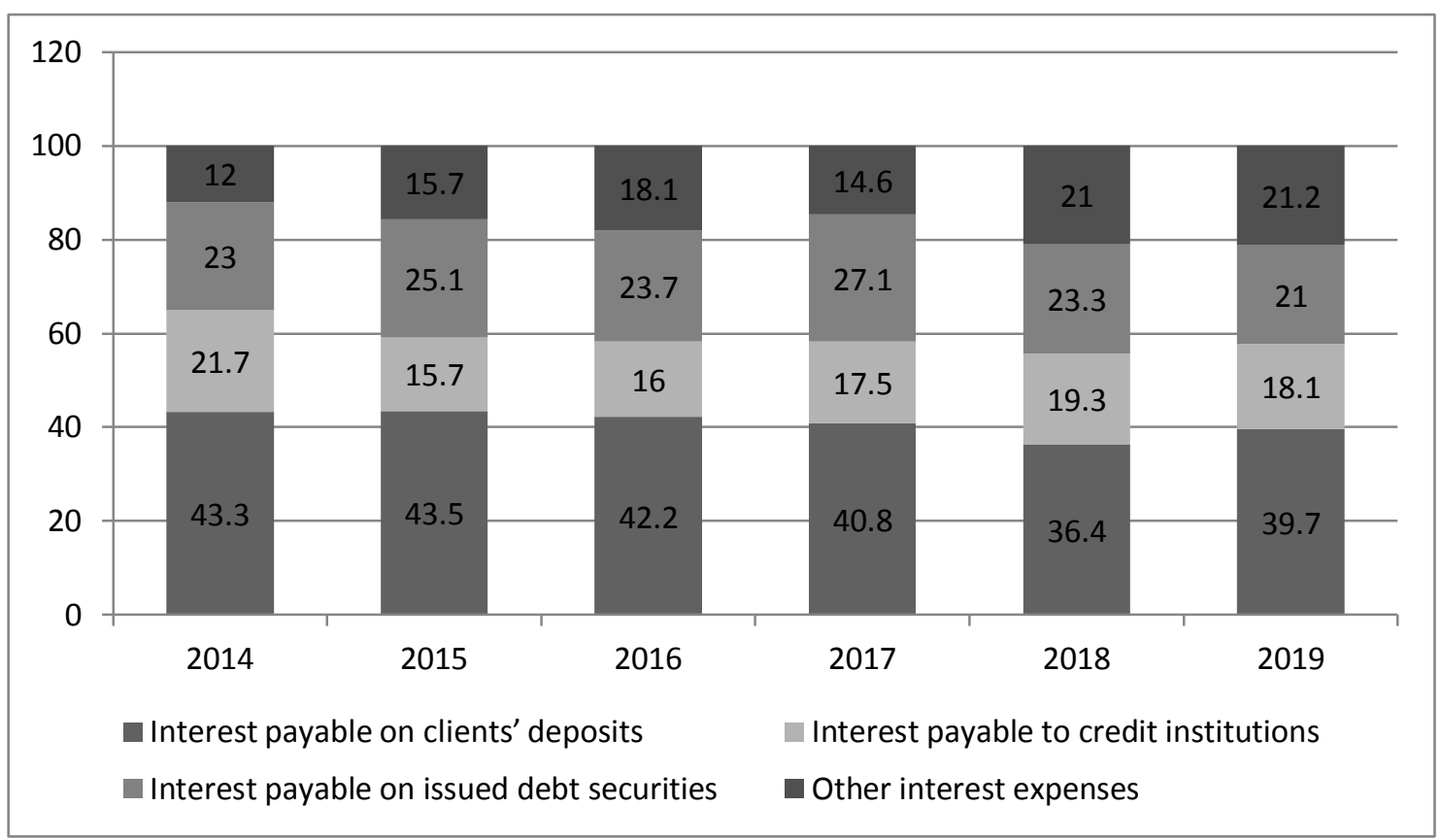

Figure 9. Composition and structure of interest expense in Latvian commercial banks in 2014-2019 (prepared by the authors basing on Latvian Financial and Capital Market Commission data, Finance Latvia Association data)

It is necessary to note that the efficiency of managing bank resources also depends on their deployment in assets. Since the aim of the resource base formation is the efficient use of the resources, this interrelated twofold process should be taken into account in bank resource management.

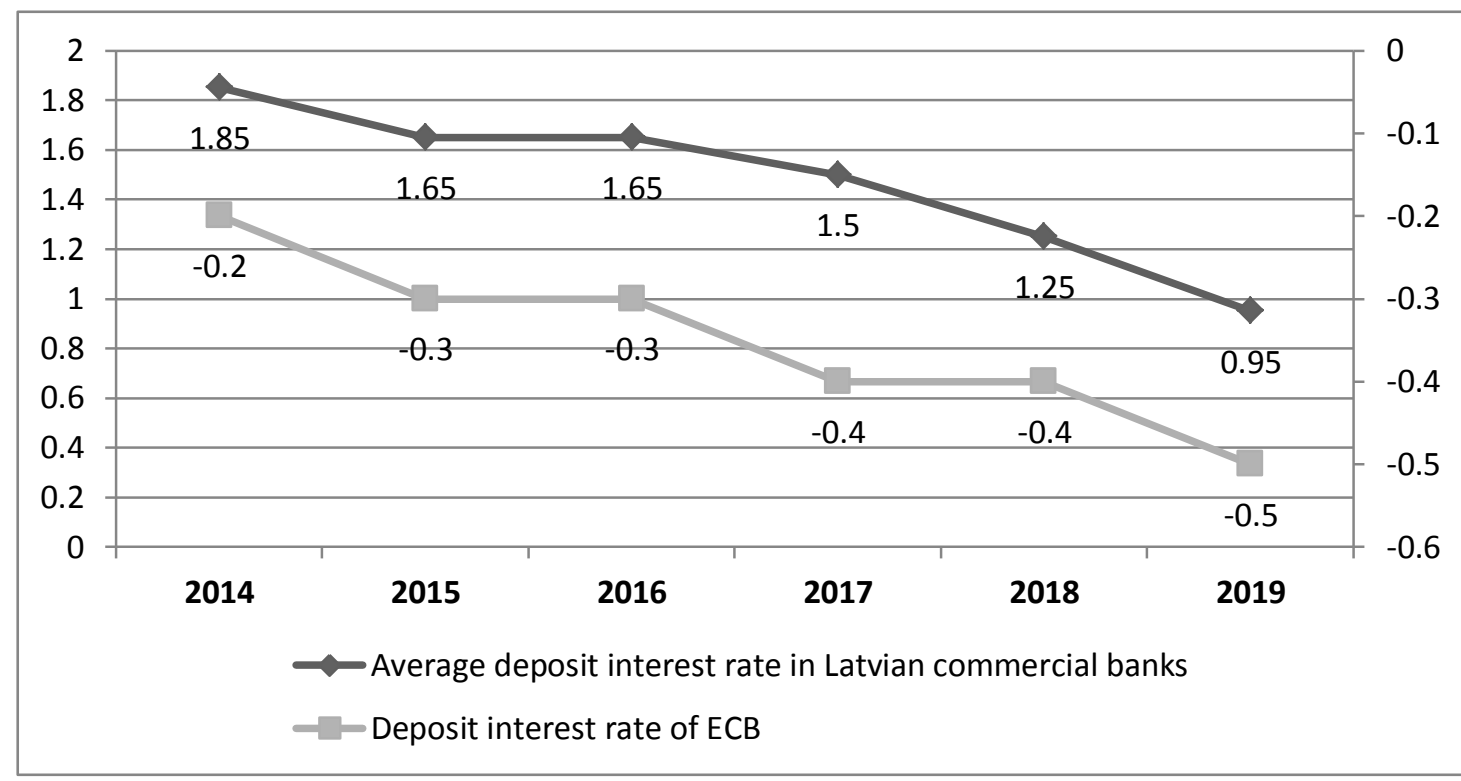

Figure 10. Dynamics of average deposit interest rate in Latvian commercial banks and deposit interest rate of European Central Bank (prepared by the authors basing on Latvian commercial banks data and European Central Bank data) 


\section{Bank Resources Management Based on Optimization of the Attraction and Allocation of Funds}

The resource base formation in commercial banks is inseparably linked with the allocation of resources in profitable active transactions. That is why resource management should be aimed at the most efficient use of the resources, maintaining at the same time the required level of liquidity (N. Konovalova (2019). In this connection, in order to improve the bank resources management, it is proposed to use the author's methodology for optimizing the attraction and allocation of bank resources. The suggested methodology consists of 4 steps and described below.

First step. The analysis of bank's financial resource base and determination of bank total resources.

The analysis of the bank's financial resource base, which presupposes quantitative identification of the stable part of resources and the possibility of their change in the future, the establishment of the relation between the bank's equity and debt, the determination of the relationship between term deposits and demand deposits as well as the identification of the stable and constant part of demand deposits. It is necessary to note that the main types of bank resources will include clients' deposits (both term and demand deposits), debt securities issued by the bank and equity capital. Such elements as subordinated liabilities, interbank loans and the balance in Loro accounts repayable on demand are supplemental bank resources. When establishing the total volume of bank resources, it is necessary to deduct from the bank's liabilities such items as deferred income and accrued expenses, provisions for the employees' holidays, deferred tax payments, accounts payable for business transactions as well as other liabilities which, in essence, cannot be considered bank resources (N. Konovalova (2019).

Second step. The analysis of bank's assets, their classification.

When analyzing the bank's assets and the allocation of resources in the bank's assets, it is advisable to group the assets by the degree of their liquidity and profitability in the following way:

Group 1 - Primary reserves: cash in bank; cash balance payable on demand in the central bank (the Bank of Latvia) and in solvent credit institutions.

Group 2 - Secondary reserves: state securities having permanent, unlimited market (i.e., they can be sold within a short period of time without significant loss); claims on the central bank (the Bank of Latvia) and on solvent credit institutions with the remaining maturity of not more than 30 days; short-term loans to solvent borrowers repayable within 30 days, the repayment of which is certain; other claims for benefit of the bank with the remaining maturity of not more than 30 days, the repayment of which is certain.

Group 3 - Short-term assets:_securities with the remaining maturity or the duration of their presence in the bank's portfolio from 31 to 360 days; claims on solvent credit institutions with the remaining maturity from 31 to 360 days; short-term loans extended to solvent borrowers with the remaining maturity from 31 to 360 days; other claims for benefit of the bank with the remaining maturity from 31 to 360 days.

Group 4 - Long-term assets (Low-liquidity assets): long-term securities with the remaining maturity or the duration of their presence in the bank's portfolio of more than 360 days; long-term loans provided to solvent borrowers with the remaining maturity of more than 360 days; claims on solvent credit institutions with the remaining maturity of more than 360 days; shares in other companies; other long-term investments.

Group 5 - Illiquid assets: overdue loans; bad debts related to securities; other bad assets.

The above grouping of assets by the degree of their liquidity and profitability makes it possible to analyze and assess the efficiency of resource allocation. It is evident that the third and the fourth group of assets are the most profitable, since short-term (up to one year) and long-term (more than one year) investment of funds ensures the maximum income for the bank. However, it is necessary to remember that the allocation of resources in these groups of assets is subject to high risk and that poor management of assets can result in the appearance of illiquid assets and, eventually, in loss. As regards primary reserves, they play the biggest role in insuring high liquidity, but at the same time they do not bring any income. Secondary reserves, as a rule, bring the bank some small income and ensure good liquidity. Characterizing the group of illiquid assets of the bank, it is necessary to note that these are the assets not bringing any income and it is very difficult, if not impossible, to turn them into money. It should be noted that the assets of the bank also include fixed assets (buildings, structures, computer equipment, vehicles, etc.), intangible assets (intellectual property, software, etc.) as well as other immobilized assets that were not placed in any of the groups of assets classified by the degree of their liquidity and profitability. The point is that the above classification of assets by the degree of liquidity is concerned with the quickness of the assets being turned into cash for meeting the bank's financial obligations to depositors. But if the bank is functioning well, there is no need to sell, for example, fixed assets or intangible assets (i.e., to turn them into cash) in order to meet the obligations to depositors. Fixed and 
intangible assets are designed to ensure the performance of the banking functions, and they can be sold only in emergency situations. From profitability point of view, fixed assets, intangible assets and other immobilized assets do not bring any income directly, playing only a supporting role in banking transactions. For this reason, they are not included in any of the groups of earning assets. As regards the source of financing the acquisition of fixed assets and intangible assets, they are acquired mainly using the bank's equity capital - i.e., the most stable part of resources. Such immobilized assets as, for example, accounts payable for business transactions and others are formed, as a rule, by using non-resource liabilities. This is followed by analysis and assessment of each group assets under above mentioned classification is evaluating and measuring by profitability. The information sources for analysis and assessment are financial reports (mainly bank balance, profit or losses report as well as appendixes to financial reports).

\section{Third step. Calculation of effective (earning) bank financial resources.}

Based on the results of the analysis of liabilities and assets (attraction and allocation of funds) the volume of effective resources is determined (i.e., the volume of resources that can bring income to the bank), taking into account the actual resource base of the bank. It appears that effective, or earning, bank resources can be determined only after creating a minimum required reserve of high-liquidity assets, as well as after channelling resources into fixed assets, intangible assets and some other types of assets withdrawn from the principle banking activities. When establishing the minimum required reserve of high-liquidity assets, it is necessary to take into account that it is determined based on the mandatory reserve requirements and liquidity coverage ratio (LCR). Thus, the minimum required reserve of high-liquidity assets can be calculated by adjusting the reserve base for the mandatory reserve norm and by determining the liquidity coverage ratio norm. For convenience in calculations, we will create a separate group of assets not included in the grouping by the degree of liquidity and profitability carried out at the second stage. This separate group of assets will represent immobilized assets (assets withdrawn from the principal banking activities). So immobilized assets will include the following elements: fixed assets, capital investment, intangible assets, inventory (excluding exchange goods), accounts receivable for the business activities of the bank, other assets withdrawn from the principal banking activities.

To calculate the effective (earning) bank financial resources the authors suggest using the following formula:

$$
R(E F)=R-\Delta I M-(M R R \times R B)-(L C R-M R R) \times N L O
$$

(Konovalova N., 2019)

$\mathrm{R}(\mathrm{EF})$ - the amount of effective (profitable) bank's resources;

$\mathrm{R}$ - total bank's resources;

$\Delta \mathrm{IM}$ - the excess of noncurrent assets over the liabilities that are not a part of bank's resources (positive difference between immobilized assets and non-resource liabilities);

MRR - minimum reserve requirements;

$\mathrm{RB}$ - reserve base;

LCR - liquidity coverage ratio = liquidity buffer /net liquidity outflows over a 30-calendar day stress period;

NLO - net liquidity outflows over a 30-calendar day stress period.

As is seen in the above formula, the amount by which immobilized assets exceed non-resource liabilities is excluded from total bank resources. In case the non-resource liabilities happen to be bigger than the total immobilized assets, i.e. the difference between immobilized assets and non-resource liabilities is negative, this difference will not be taken into account. The negative difference between immobilized assets and non-resource liabilities will lead to the increase of the total resource base of the bank, which, in the authors' opinion, is not right, since in this case resources would include non-resource obligations. In accordance with the banking legislation, each commercial bank must observe the minimum reserve requirements, which are established in per cent of the bank's reserve base. In its turn, the amount of the mandatory reserve will be a high liquidity, but unprofitable asset reserve adequate to the minimum reserve requirements. Therefore, this amount (MRR x RB) also needs to be subtracted from total bank resources as part of resources which the bank is obliged to maintain in a highly liquid form. Each state has its own minimum reserve requirements and its own elements of the reserve base. Moreover, depending on the aims of the country's monetary policy, the minimum reserve requirements may change, as well as the elements of the reserve base also can be changed. Besides the mandatory reserve ratio, commercial banks have to observe the norm of liquidity coverage ratio (LCR), which is determined as the ratio of the bank's liquidity buffer to its net liquidity outflows over a 30-calendar day stress period. But since the compliance with the current liquidity norm (liquidity coverage ratio) is partially reflected in the amount of minimum reserve required, the current liabilities subject to mandatory reserve 
requirements need to be adjusted for the minimum required reserve ratio and net liquidity outflows over a 30-calendar day stress period ((LCR - MRR) x NLO) and then subtracted from total bank resources. It is means that the amount of resources equivalent to the norm of liquidity coverage ratio must be subtracted from total bank resources. Thus, by excluding from total resources a certain part thereof which has to be maintained in a highly liquid form and also, because of different circumstances and the peculiarities of the bank's activities, has to be allocated in immobilized assets (withdrawn from the principal banking activities), we get the volume of effective (earning) bank resources. It is necessary to note that at this stage not the actual effectiveness, but the actual availability in the bank of effective (earning) resources is determined, based on the existing liabilities structure.

Fourth step. Evaluation of an optimization of attraction and placement (allocation) bank financial resources.

After determining the existing volume of earning bank resources, it is necessary to assess their real (actual) effectiveness. This can be done by comparing the actual volume of earning assets, established at the second stage, with the available volume of effective bank resources, established at the third stage.

The comparison can result in three variants:

1) the volume of effective (earning) resources equals the actual volume of earning assets;

2) the volume of effective (earning) resources is bigger than the actual volume of earning assets;

3 ) the volume of effective (earning) resources is smaller than the actual volume of earning assets.

If the volume of effective (earning) resources equals the actual volume of earning assets, it is means that management of financial resources at the bank is on the high level, and structure of attraction and allocation of bank resources under matches of liquidity and profitability is balanced and optimized. In this case the benchmark of compliance between profitability and liquidity is perfect. But in real life banks conducting their activity can't mountain ideal balancing between liquidity and profitability and have mismatches between them. These mismatches can be characterized by lack of free financial resources or by surplus free financial resources. Thus, if a free volume of unprofitable resources has been identified, it is necessary to change the structure of bank assets so as to deploy the available free resources in earning active transactions (credits, investments, etc.) for increasing the bank's profitability. If a lack of resources has been identified, it is necessary to take the following steps:

a) to procure additional resources (by attracting term deposits and demand deposits from the clients);

b) to take short-term interbank loans;

c) to regroup the bank's assets so as to increase the share of highly liquid assets and to decrease the share of very risky assets (for example, to use the repaid loan money not for extending new loans, but for replenishing the resources; to use the money received from selling securities for replenishing the resources, etc.);

d) to regroup the bank's liabilities so as to increase the share of term deposits by offering different types of deposit programmes;

e) to increase the equity capital of the bank (either by profit capitalization or by raising subordinated capital).

\section{Implications for Latvian Commercial Banks}

At the present time there are 13 commercial banks in Latvia, which operate in financial market, attract financial resources and provide allocations of financial resources in asset operations. The authors provide the calculations and comparison of the amount of effective (profitable) resources with the actual amount of earning assets in all 13 Latvian commercial banks based on suggested methodology for optimizing the attraction and allocation of bank resources, which was considered above in previous section on the paper. Table 1 shows the calculations of effective (profitable) resources, the actual amount of profitable assets and the surplus of free funds for all 13 Latvian commercial banks. As noted above, for optimizing the attraction and allocation of bank resources while ensuring the required level of liquidity and achieving the maximum possible level of profitability, it is necessary to strive for the equality of earning assets and effective (earning) resources. However, an analysis of the comparison between the availability of effective resources and the availability of profitable assets showed that all commercial banks in Latvia operate with a surplus of free resources. The calculations in Table 1 confirm that Latvian commercial banks operate with a surplus of free resources. This is evidence for the fact that Latvian commercial banks do not rationally utilize resources at their disposal, as well as the fact that there are limited possibilities for Latvian banks to effectively place assets on the markets.

For comparison of the amount of effective resources and actual amount of earnings assets for different banks, the relative indicators, which describe the share of surplus of free resources in the total volume of effective (profitable) 
resources for the bank, are the most appropriate. The smaller the share of free resources surplus, the more effectively does the bank operate, and when the share of free resources surplus increases, the effectiveness of bank's operations decreases. Consequently, the relative indicators of free resources surplus determine the level of inefficient utilization of resources which determines the amount of bank profits forgone.

Authors revealed the smallest and the biggest share of effective resources in Latvian commercial banks. Thus, the share of effective resources in Latvian commercial banks in 2019 is fluctuated from 53.25\% to $85.77 \%$. The biggest share of effective resources is defined in the Expobank (85.77\%). The smallest share of effective resources is identified in the Signet Bank (53.25\%). The share of actual earning assets in Latvian commercial banks is quite small and fluctuated from $26.87 \%$ to $45.18 \%$ in 2019 . It means that Latvian commercial banks use their financial resources not fully and insufficiently effective. The biggest share of actual earning assets is revealed in the Baltic International Bank (45.18\%) and the smaller share of actual earning assets is identified in the Privat Bank (26.87\%). Accordingly, at the present time, commercial banks in Latvia work with a surplus of free funds and have reserves of increasing of their profitability.

Table 1. Comparison of the amount of effective (profitable) resources with the actual amount of earning assets in Latvian commercial banks (\%), 31.12.2019 (calculated by the authors basing on Latvian Financial and Capital Market Commission data, Finance Latvia Association data, and Latvian commercial banks data)

\begin{tabular}{clcccc}
\hline No & \multicolumn{1}{c}{$\begin{array}{c}\text { Latvian commercial } \\
\text { banks }\end{array}$} & $\begin{array}{c}\text { Total bank } \\
\text { resources } \\
\mathrm{R}\end{array}$ & $\begin{array}{c}\text { Share of } \\
\text { effective } \\
\text { resources, } \\
\mathrm{R}(\mathrm{EF})\end{array}$ & $\begin{array}{c}\text { Share of actual } \\
\text { earning assets, } \\
\text { A (EARN) }\end{array}$ & $\begin{array}{c}\text { Surplus (+) } \\
\text { of free } \\
\text { resources }\end{array}$ \\
\hline 1. & Baltic International Bank & 100.00 & 78.25 & 45.18 & +33.07 \\
2. & Blue Orange Bank & 100.00 & 82.55 & 39.40 & +43.15 \\
3. & Citadele Banka & 100.00 & 70.30 & 38.15 & +32.15 \\
4. & Expobank & 100.00 & 85.77 & 28.50 & +57.27 \\
5. & Industria Bank & 100.00 & 65.18 & 39.75 & +25.43 \\
6. & LPB Bank & 100.00 & 69.45 & 27.30 & +42.15 \\
7. & Privat Bank & 100.00 & 70.05 & 26.87 & +43.18 \\
8. & Regional Investent Bank & 100.00 & 75.90 & 37.45 & +38.45 \\
9. & Rietumu banka & 100.00 & 72.18 & 34.80 & +37.38 \\
10. & Rigensis Bank & 100.00 & 58.33 & 35.49 & +22.84 \\
11. & SEB Banka & 100.00 & 64.22 & 42.21 & +22.01 \\
12. & Signet Bank & 100.00 & 53.25 & 28.78 & +24.47 \\
13. & Swedbank & 100.00 & 68.30 & 35.15 & +33.15 \\
\hline
\end{tabular}

The results of the comparing of different banks allowed the authors to make conclusions that one commercial banks (Expobank) work with the largest surplus of free financial resources (ranging more than 50\%). 8 commercial banks (Baltic International Bank, Blue Orange Bank, Citadele Banka, LPB Bank, Privat Bank, Regional Investment Bank, Rietumu banka and Swedbank) are the banks that operate with the middle level of surplus of free financial resources (the range of free resources fluctuations for these 8 banks varies from $25 \%$ to $50 \%$ ). The more moderate range of surplus free financial recourses is observed for 4 banks (Industria Bank, Rigensis Bank, SEB Banka and Signet Bank). These 4 banks work with surplus of financial resources less than 25\% (Table 1). Take into consideration this fact, authors make conclusion that Latvian commercial banks have a big reserve of free resources and have yield growth reserves. In this regard further research can be devoted to the study of yield growth reserves determination in commercial banks in Latvia as well as in commercial banks of other countries.

\section{Conclusions}

Based on the results of the research the authors have formulated the following conclusions. 
1) Clients' deposits account for the biggest share of funding sources. However, in recent years the growth rates of clients' deposits are decrease and have a negative tendency.

2) The share of capital and reserves in Latvian commercial banks does not exceed $12 \%$ of total bank resources. When analyzing the capital adequacy dynamics, it is possible to make a conclusion that this indicator, in the system of Latvian commercial banks, is quite stable and varies between $20 \%$ and $22 \%$.

3) Latvian commercial banks are rather active in using the source of internal capital growth by increasing the share of retained earnings in it. Thus, during the analysed period, the share of retained earnings accounted for more than $10 \%$ of the funding sources. The highest share of retained earnings was in 2016 and accounted $25 \%$.

4) The return on equity in the system of Latvian commercial banks is decreasing and breakdown of this indicator was essential during the analyzed period (2014-2019). The return on equity was decreased from $11.07 \%$ in 2014 to $4.53 \%$ in 2019.

5) The analysis of debt resources (liabilities) in Latvian commercial banks during a 6-year period, from 2014 to 2019 , showed that deposit resources make up the highest share $(80-86 \%)$. In turn, in the composition of deposit resources, the largest share is occupied by demand deposits, which are the main source of placement of funds in active short-term operations. But in the Latvian banking system there has been a rate of decline in demand deposits due to the fact that many banks have reduced the service of non-resident customers' accounts.

6) Financial resources attracting is associated with costs, namely, interest expenses of the bank. The authors revealed that interest expenses amount a small share of the total expenses of Latvian commercial banks. Thus, it was found that for the analyzed period from 2014 to 2019, the share of interest expenses in total expenses fluctuated from $9.7 \%$ to $12.7 \%$ only. The factor of negative interest rate of the European Central Bank also significantly affected the decrease in total interest costs of banks.

Based on the findings and results of the research the authors have developed the following recommendations for Latvian commercial banks on improving their resource management.

1) In equity capital management, to carry out long-term capital planning based on the general financial plan of the bank. This will allow the banks to plan resources more efficiently and to procure long-term resources in accordance with the expected active transactions.

2) To forecast dividend payments in order to determine the possibility of using internal sources for increasing the capital.

3) To optimize the size and the composition of Tier 1 and Tier 2 capital elements based on long-term planning of capital.

4) In liability management, the banks need to control the level of interbank loans and to make sure that they do not turn into a permanent funding source.

5) In bank resources management, to use the methodology for optimizing the attraction and allocation of funds, proposed by the authors.

6) To calculate the effective (earning) resources of the bank using the formula, proposed by the authors.

7) To monitor the correspondence between earning resources and earning assets. In case the amount of earning resources exceeds the amount of earning assets, to find opportunities for the efficient allocation of surplus earning resources. In case the amount of earning assets exceeds the amount of earning resources, to regroup the assets increasing the share of highly liquid assets and to procure additional earning resources by increasing equity capital, attracting subordinated liabilities, attracting deposits, issuing debt instruments and using other sources.

\section{References}

Adam, A. (2008). Handbook of Asset and Liability Management: From Models to Optimal Return Strategies. The Wiley Finance Series: Hardcover, Jan. 2.

Alper, D., \& Anbar, A. (2011). Bank Specific and Macroeconomic Determinants of Commercial Bank Profitability: Empirical Evidence from Turkey. Business and Economics Research Journal, 2(2), 139-152.

Asiri, B. K. (2007). Assets-liabilities management in banks: A case of Kuwait. Indian Journal of Economics and 
Business, 6(1), 103-115.

Baltic International Bank. Retrieved 30 July 2020, from https://www.bib.eu/

Barmuta, K., Ponkratov, V. V., Maramygin, M., Kuznetsov, N. V., Ivlev, V., \& Ivleva, M. (2019). Mathematical model of optimizing the balance sheet structure of the Russian banking system with allowance for the foreign exchange risk levels. Entrepreneurship and Sustainability Issues, 7(1), 484-497. https://doi.org/10.9770/jesi.2019.7.1(34)

Basel Committee on Banking Supervision. Retrieved 20 July 2020, from http://www.bis.org/

Blue Orange Bank. Retrieved 30 July 2020, from https://www.blueorangebank.com/int/en

Choudhy, M. (2007). Bank Asset \& Liability Management: Strategy, Trading, Analysis. Wiley Finance: Hardcover, April 13.

Citadele Banka. Retrieved 30 July 2020, from https://www.citadele.lv/en/

Dalessandro, A. (2013). Effective Strategies for Assets and Liabilities Management. SSRN. Retrieved from https://ssrn.com/abstract=2394622

Fabozzi, F. J., \& Konishi, A. (1995). Asset-liability Management. New Delhi: S. Chand \& Co.

Finance and Capital Market Commission FCMC), Statistics. Retrieved 20 July 2020, from https://www.fktk.lv/statistika/kreditiestades/ceturksna-parskati/

Finance Latvia Association, Statistical data. Retrieved 20 July 2020, from https://www.financelatvia.eu/en/industry-data/

Francis, M. E. (2007). Determinants of Banks’ Profitability in Sub-Saharan Africa, 30(2).

Golbert, L., \& Rai, A. (1996). The structure-performance relationship for European banking. Journal of Banking and Finance, 20, 745-771.

Gunay, G., Ozkan-Gunay, E. N., \& Tektas, A. (2005). Asset and liability management in financial crisis. The Journal of Risk Finance, 6(2), 135-149.

Herianingrum, S., Ratnasari, R. T., Widiastuti, T., Mawardi, I., Amalia, R. C., \& Fadhlillah, H. (2019). The impact of Islamic bank financing on business. Entrepreneurship and Sustainability Issues, 7(1), 133-145. https://doi.org/10.9770/jesi.2019.7.1(11)

Industria Bank. Retrieved 30 July 2020, from https://www.luminor.lv/

Konovalova, N. (2019). Management of Liquidity and Profitability in Commercial Banks. Reliability and Statistics in Transportation and Communication, Lecture Notes in Networks and Systems, book series, (vol. 68, pp. 725-736). $\begin{array}{llll}\text { Springer } & \text { International Rublishing. } & \text { Retrieved from }\end{array}$ https://link.springer.com/chapter/10.1007\%2F978-3-030-12450-2_70

Kosmidou, K., Pasiouras, F., \& Floropoulos, J. (2004). Linking profits to asset-liability management of domestic and foreign Banks in the UK. Applied Financial Economics, 14, 1319-1324.

Kwast, M. L., \& Rose, J. T. (1982). Pricing, operating efficiency, and profitability among large commercial banks. Journal of Banking and Finance, 6, 233-254.

Larionova, I. V. (2003). Asset liability management in commercial bank. Moscow: Konsaltbankir.

Larionova, I. V. (2015). Risk management in commercial bank. Moscow: Knorus.

Lavrushin, O. I. (2012). Bank management. Moscow: Knorus.

LPB Bank. Retrieved 30 July 2020, from http://www.lpb.lv/en/

Mikhaylova, A. A., Mikhaylov, A. S., Savchina, O. V., \& Plotnikova, A. P. (2019). Innovation landscape of the Baltic region. Administratie si Management Public, (33), 165-180, https://doi.org/10.24818/amp/2019.33-10

Mokhova, N., Zinecker, M., \& Meluzín, T. (2018). Internal factors influencing the cost of equity capital. Entrepreneurship and Sustainability Issues, 5(4), 827-845. https://doi.org/10.9770/jesi.2018.5.4(9)

Peter, S. R. (1996). Commercial Bank Management (3rd ed.) Irwin.

Peter, S. R. (2012). Bank Management \& Financial Services (9th ed.). McGraw-Hill Education.

Privat Bank. Retrieved 30 July 2020, from https://www.privatbank.lv/en/ 
Ramlall, I. (2009). Bank-Specific, Industry-Specific, and Macroeconomic Determinants of Profitability in Taiwanese Banking System: Under Panel Data Estimation. International Journal of Finance and Economics, 34, 160-167.

Regional Investment Bank. Retrieved 30 July 2020, from http://www.ribbank.com/en/

Rietumu banka. Retrieved 30 July 2020, from http://www.rietumu.com/

Rigensis Bank. Retrieved 30 July 2020, from http://www.rigensis.lv/en/

Rosen, D., \& Zenios, S. A. (2006). Enterprise-wide asset and liability management: issues, institutions, and models. Handbook of Asset and Liability Management Theory and Methodology, 1(1).

Saksonova, S., \& Kantāne, I. (2016). Mergers and Acquisitions: Examples of Best Practice in Europe and Latvia. Contemporary Issues in Finance: Current Challenges from Across Europe, 98, 95-110. https://doi.org/10.1108/S1569-375920160000098007

Saksonova, S., \& Koḷeda, O. (2017). Evaluating the Interrelationship between Actions of Latvian Commercial Banks and Latvian Economic Growth. Procedia Engineering, 178, 123-130. https://doi.org/10.1016/j.proeng.2017.01.075

SEB Banka. Retrieved 30 July 2020, from https://www.seb.lv/eng

Shubiri, A. (2010). Impact of Asset and Liability Management on Profitability: Empirical Investigation. Amman Arab University, College of Commerce Press, 2(4), 101-109.

Signet Bank. Retrieved 30 July 2020, from https://www.signetbank.com/

Sinkey, J. F. Jr. (2002). Commercial Bank Financial Management in the Financial Service Industry (6th ed.). New York, Macmillan Publishing Company.

Swedbank. Retrieved 30 July 2020, from https://www.swedbank.lv/

Tamiru, B. (2013). Asset Liability Management and Commercial Banks Profitability in Ethiopia. Research Journal of Finance and Accounting, 4(10).

Tatibekova, A., \& Bubeyev, M. (2020). How regulation of bank capital adequacy and liquidity affects pricing of bonds of the banks. Entrepreneurship and Sustainability Issues, 7(3), 1708-1722. https://doi.org/10.9770/jesi.2020.7.3(18)

Tee, E. (2017, June). Asset Liability Management and the Profitability of Listed Banks in Ghana. https://doi.org/10.9790/5933-0803040914

\section{Copyrights}

Copyright for this article is retained by the author(s), with first publication rights granted to the journal.

This is an open-access article distributed under the terms and conditions of the Creative Commons Attribution license (http://creativecommons.org/licenses/by/4.0/). 